\title{
Erratum to: Information and Communications Technology Effects on East Asian Productivity
}

\section{Elsadig Musa Ahmed}

Published online: 31 August 2010

(C) Springer Science+Business Media, LLC 2010

\section{Erratum to: J Knowl Econ \\ DOI 10.1007/s13132-010-0013-8}

In Table 2, the heading "Adjusted" should actually read "Adjusted $\mathrm{R}^{2}$ ".

The online version of the original article can be found at http://dx.doi.org/10.1007/s13132-010-0013-8.

E. M. Ahmed $(\square)$

Economics Unit, Faculty of Business and Law, Multimedia University, 75450 Melaka, Malaysia e-mail: elsadigmusa@yahoo.com

e-mail: asadiq29@hotmail.com 